\title{
Ética em Pesquisa
}

Mudou o mundo, os costumes e as leis. Hoje, as pesquisas necessitam e precisam do aval da Instituição em que são realizadas. Elas tomaram consciência e se tornaram co-responsáveis, como soe de direito, do que acontece dentro de seus domínios. Com isto, as pesquisas que envolvem seres humanos, geraram uma nova ciência - a Bioética. Comitês de Bioética foram criados nas Instituições que pesquisam. Eles têm por finalidade estudar e levar em consideração todos os aspectos envolvidos e nos orientar da ética que devemos seguir para tornar nossas pesquisas dentro do respeito que devemos àqueles que nos permitem realizá-las e que necessitam de nossos estudos.

\section{A Diretoria}

